\title{
STUDENTS' SELF-EFFICAC Y In IN PUBLIC SPEAKING PROGRAM AT SMKN 1 LAMONGAN
}

\author{
Intan Nuvitasari ${ }^{1}$, Rizka Safriyani $^{2}$, Rakhmawati $^{3}$ \\ English Teacher Education Department, \\ Faculty of Education and Teacher Training, \\ Sunan Ampel Islamic University \\ Indonesia \\ intan_nuvitasari23@gmail.com ${ }^{1}$,rizkasafriyani@uinsby.ac.id ${ }^{2}$, thestarone_777@yahoo.com ${ }^{3}$
}

\begin{abstract}
Public speaking anxiety is becoming the common problem which is faced by students. In fact, it is known while the students are performing public speaking. State vocational high school 1 Lamongan often participated public speaking competition, but the result of participating some competition, the students need to improve skill in public speaking as teacher's interview result. Thus, public speaking program was held by the teacher as cooperation by SMKN 1 Lamongan and UIN Sunan Ampel Surabaya. By the case, therefore, it needs analyzing way to know the students' readiness before performing speech by analyzing students' self-efficacy in performing prepared speech. Prepared speech is one of public speaking's types. This study focused on identifying students' self-efficacy level in prepared speech, identifying factors influencing students' self-efficacy in prepared speech and identifying teacher's strategy in improving students' self-efficacy in prepared speech. The researcher determines this study as qualitative case study using descriptive approach. The participates were from nineteen students of eleventh and twelfth grade. To answer the research problems, the researcher uses interview and questionnaire as the techniques to achieve the aims of this study. The result of this study shows that there are eight students who are in high level, six students in moderate level and five students in low level. The factors which influence students' self-efficacy in prepared speech are performing speech experience, vicarious experience, verbal persuasion and emotional state. There are also new factors which become the first factor influencing students' selfefficacy. Those are confidence, ability, doubt and do not have any experience. Then, to improve students' self-efficacy, the teacher used plan moderately challenging task, use peer models, affective strategy, social strategy and fun learning strategy.
\end{abstract}

\section{Key Words: Students'Self-Efficacy, Prepared Speech}

\section{INTRODUCTION}

Public speaking is one of program for some selected students at State Vocational High School 1 Lamongan which is preparing students to have ability in public speaking to join competition. It is required students to have speaking ability through speech, debate and being presenter in public area. As Lisa Shraiber, Ph.D. stated that public speaking is presenting speech through formal way in a public. She also stated that public speaking is not about how to speak in public only, but it is also about how to make the audience remember and understand what the speaker delivers to them. Thus, in joining public speaking competition, the participants must be well understand about how to deliver public speaking, in order to, they may deliver their material to audience and make the audience understand about what the participant's material is.

According to the interview with the public speaking's teacher, State Vocational High School 1 Lamongan has contributed in public speaking competition in Students' Activity Competition which is held by East Java Province, but the problem of the participants, they have minimum skill in performing public speaking. In fact, performing public speaking needs skill. As Lisa Shraiber, $\mathrm{PhD}$ stated that there are some competencies which are needed in performing public speaking well; useful topic, clear organization, clear language, suitable vocal expression, adapted the audience and convincing persuasion. To reach this goal, this school needs self-efficacy analysis to know the students' readiness in performing public speaking and it also leads to know whether they are getting fear or not since getting fear lead the students to not be ready to perform their public speaking.

As Albert Bandura stated that self-efficacy is personal judgment about themselves in executing and perform an educational task. In perceiving self-efficacy can be influenced by cognitive stress in psychological. Thus, it can be concluded that fear can influence someone's selfefficacy.

Self-efficacy is as one way in analyzing to know the students' belief in public speaking since self-efficacy is analyzed before the students perform the relevant activities. As Albert Bandura stated that self-efficacy is as a way to analyses people before performing task, but someone's selfefficacy can be compared while they are performing or it can be compared with the result of activity that is analyzed. According to Albert Bandura, self-efficacy is people's belief about their capabilities in executing something and it is related with their feeling, motivation, thinking and behavior. Thus, self-efficacy is very needed to know someone's belief about their capability in a subject since it has been stated before that self-efficacy analyses about someone's capability in specific subject. Albert Bandura also stated that selfefficacy will affect four processes of human's life. The four processes are cognitive process, motivational process, affective process and selection process. Cognitive process covers human behavior which is organized by thought. Motivational process covers form belief to reach human's goal. Affective process covers human's interpretation of depression into positive way, such as: they are stress with their job, but they reduce stress by thinking that job is for future life. Selection process is selection of activities that human can handle the activity and it is influence the 
environment. Thus, it can be concluded that people who has high self-efficacy, it leads them to have good control in themselves since self-efficacy will affect human's life

Therefore, the researcher conducted this research by narrowing three research questions: 1 . what level is the students' self-efficacy in prepared speech? 2. What are the factors' influencing students' self-efficacy in public speaking, what are the strategies used by the teacher to improve students' self-efficacy?

\section{LITERATURE REVIEW}

\section{a. Self-Efficacy}

Self-efficacy in education is related with perceiving self-efficacy in academic. Perceived selfefficacy in academic is about someone's judgement on their capability to organize and execute courses of action to achieve designated types of educational performance. On educational development, perceived self-efficacy is about how efficacy affect student's motivation to learn, to effort in execute task and student's achievement. Thus, it can be concluded that perceived self-efficacy is about someone' belief in execute subjects to gain their educational performance and it also effect on their learning motivation, effort and their education's achievement.

Actually, self-efficacy influence level of effort, persistence and choice of activities. Thus, Bandura also stated that someone who has high self-efficacy, they will execute difficult tasks as challenging tasks that will be mastered rather than they avoid the tasks. Students with high sense of efficacy, they will participate more readily, work harder and persist longer when encounter difficulties task. Then, someone who has low selfefficacy will avoid difficult task. Indeed, someone with high self-efficacy will be more challenging to execute difficult task and someone with low self-efficacy are lack of challenging in execute difficult task.

According to Albert Bandura, there are four factors which are influenced self-efficacy which describe as follow:

\section{Mastery Experience}

Mastery experience occur when someone attempts to do something and are successful. Thus, we master from the experience. Mastery experience is as the strongest way in buildup self-efficacy because people are most likely to believe that they can do something new if it is similar to something that they have already done before.

2. Vicarious Experience

Vicarious experience is happening by looking at other people who did the same thing with you, so it will occur if you look at people who did same thing with you and they are successfully execute the thing and it will increase your self-efficacy, but if you look at someone who did same thing with you and they are failure and it will make you have same perception of it and it will decrease your selfefficacy.

3. Verbal Persuasion

Verbal persuasion occurs when someone is persuaded verbally that they can achieve or master a task, then they more likely to do the task well, but if people are said that they do not have ability to accomplish the task, they will give up to accomplish the task.

4. Emotional States

Emotional state occurs when someone think that they likely cannot accomplish a task and it will be happened if people think about negative think while they accomplish the task. Stress and anxiety are as big fear and it will affect someone's self-efficacy, but anxiety and stress will not affect to someone's self-efficacy if they interpret their stress as positive, such as they think that if I'm getting nervous, I will not be success to this task.

In factors influencing self-efficacy in second language acquisition, there are also some other factors which is regarding to other research. The research is regarding self-efficacy in second/ foreign language learning. The factors are also as new findings in the research. Saeid Raoofi, Bee Hoon Tan and Swee Heng Chan research found new factors affected learners' self-efficacy. They found that learners' interest, knowledge in the content area, positive feedback from others, social and cultural context, task difficulty, classroom climate, confident, comfort due to learning process are affected learner's self-efficacy. By the new findings in factors influencing self-efficacy, this research probably have the new finding in factors influencing self-efficacy which as same as the research of Saeid Raoofi, Bee Hoon Tan and Swee Heng Chan.

\section{b. Public Speaking}

As Lisa Shraiber, Ph.D. stated that public speaking is presenting speech through formal way in a public. She continued her statement by saying that public speaking is not only about speaking in a public, but it is also about how you make your audience remember and understand what you have said. Being professional in your job, you must be able to speak and communicate with others well since it leads you to have qualities in your job. Therefore, public speaking is performing speaking in public through formal way, but the speaker must be able to make the audience understand with the material which deliver by the speaker.

Based on Discovering the treasure of public speaking book, there are five types of public speaking:

1. Impromptu Speech

Impromptu speech is a form of speech where the speech is delivered by no preparation, but it should be delivered in the same manner as a prepared speech. impromptu speech involves the writer to write speech text at the time when the writer will deliver their speech.

2. Prepared Speech

Prepared speech is a form of speech where the speech is well prepared and it is purpose to persuade and to inform the reader about topic that based on speaker's interest and experience.

3. Demonstration

Demonstration is presenting an idea with visual aids which is purpose to teach the audience.

4. Presentation

Presentation is giving information or giving insight about a topic in an auditorium.

5. Reports 
Report is a form of giving report about something that has been done, such as committee report.

From five types of public speaking above, this research used prepared speech since at State Vocational High School 1 Lamongan used prepared speech in public speaking program.

\section{c. Self-Efficacy and Public Speaking}

As Bandura stated that self-efficacy in education is related with perceiving self-efficacy in academic. Perceived self-efficacy in academic is about someone's judgement on their capability to organize and execute courses of action to achieve designated types of educational performance. On educational development, perceived self-efficacy is about how efficacy affect IV. student's motivation to learn, to effort in execute task and student's achievement. Thus, it can be concluded that perceived self-efficacy is about someone' belief in execute subjects to gain their educational performance and it also effect on their learning motivation, effort and their education's achievement.

\section{d. Level of Self-Efficacy and Public Speaking}

As Bandura stated that perceived self-efficacy cannot fit to all skills. It might be different one to each

other since one skill might have different successful criteria, but the scale on perceived self-efficacy is the same one to other. By the statement, it means that successfull criteria in perceiving self-efficacy depends on skill that investigated by the researcher. This study is focused on speech, so it has its successful criteria that might be different with other skills, but the scale in perceiving self-efficacy is the same to identify high, moderate and low.

According to Sellnow, there are four primary components to an effective speech: content, structure, delivery, and the effective use of presentational aids. Content consists of the main topic of a speech, the main points used to support the main topic, and the evidence used to clarify, explain, or support the main points. For example, a student may choose to deliver his or her speech on "the benefits of exercise," and discuss both the physical and mental health benefits of exercise. He or she might support those main points with research that suggests that exercise decreases body weight and one's risk for diseases.

To identify someone's self-efficacy, each subject has different aspect with other subject, but identifying response scale of self-efficacy is same for all subjects. Below is types of response scale in selfefficacy:

Figure 2.1. Level of Self-Efficacy

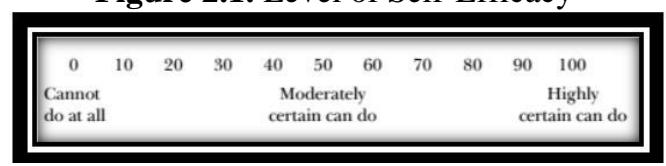

In the standard methodology for measuring self-efficacy beliefs, individuals are presented with different levels and strength. There are three levels in self-efficacy scale. It is started by 0 scale to 100 scale. 0 point scale shows that someone cannot do at all. Then, after 0 point to 30 -point scale shows that someone is in low level since they just can execute few aspects. Then, 31 point to 69 is categorized moderate level since someone moderately can do some aspects in the subject. The third level is high level. It is started 70 point to 100 point since someone can do most aspect in subject, but 100-point scale is the highest scale since someone highly certain can do all aspects in a subject.

\section{METHODOLOGY}

This research is designed using qualitative descriptive method since this research describes based on the reality. In this study, data were collected by techniques of conducting questionnaireand interview. First, the researcher did questionnaire with the students. Last, the researcher interviewed the students and the teacher who encounter public speaking program at State Vocational High School 1 Lamongan.

\section{Result and Discussion}

a. Result

Level of Students' Self-Efficacy in Prepared Speech at SMKN 1 Lamongan

The result of analyzing those data was displayed in this following form of percentage chart to show the students' level of self-efficacy in prepared speech.

Chart 4.1 Students' Self-Efficacy in Prepared Speech

\begin{tabular}{|rc|}
\hline & $\begin{array}{c}\text { Students' Self-Efficacy in Prepared Speech at } \\
\text { SMKN 1 Lamongan }\end{array}$ \\
$120 \%$ & \\
$100 \%$ \\
$80 \%$ \\
$60 \%$ \\
$40 \%$ \\
$20 \%$ \\
$0 \%$
\end{tabular}

\section{:High $\square$ :Moderate $\square$ :Low}

There are three levels which get by the students; High, Moderate and Low. In high level of self-efficacy, there are eight students in this level with various percentages; $100 \%, 95 \%, 80 \%$ and $75 \%$. In moderate level of self-efficacy, there are six students who are in this level. There are various percentage in this level; 65\%, 60\% and 55\%. Then, there are five students who are in low level. In low level of self-efficacy, there are three types percentage which get by the students; $30 \%, 20 \%$ and $15 \%$.

\section{The Factors Influencing Students' Self-Efficacy in Prepared} Speech at SMKN 1 Lamongan.

The students' self-efficacy in prepared speech is influenced by some factors. In this study, the data of students' self-efficacy of factors in prepared speech were obtained from interview with students who join public speaking program at SMKN 1 Lamongan. The interview results are described as follows:

\section{a. Speech Experience}

Speech experience or mastery experience becomes one of factors that influence students' self-efficacy in prepared speech. As the result of interview, eleven students stated that their past experience in performing prepared speech lead them to learn from their past experience. Student 5, student 3 , student 4 , student 6 , student 7 , student 12 , student 15, student 16, student 19 master from their past experience. In contrast, Student 14 has past experience in 
performing speech, but she does not master from her past experience. For her, it is better to master how to deliver speech by her teacher since she will learn directly from her teacher.

\section{b. Vicarious Experience}

The second factor is vicarious experience. Interviewing nineteen students, but there are only six students who are adapted other people in performing speech. They are Student 3, Student 4, Student 5, Student 7, Student 13 and Student 19. Dealing with vicarious experience, the students stated that they are adapted others.

Nevertheless, students who do not have vicarious experience, they said that it is better for them to have experience first. Then, they learn from their mistake. Thus, it leads them to have better quality in performing speech.

c. Verbal Persuasion

Verbal persuasion becomes one of factors which influence someone's self-efficacy. Based on interview with nineteen students, there are fourteen students that stated they were influenced by verbal persuasion. Student 2, student 3, student 4 , student 5 , student 6 , student 7 , student 8 , student 16 , student 19 get verbal persuasion from their friends and their family. Thus, it makes them believe that they can perform prepared speech.

In contrast, Student 10, Student 11, Student 13 and Student 17 have people who support and pursue them that they can perform public speaking well if they always learn how to perform it well, but it does not affect their belief since they think that they do not have experience in public speaking so they think that they cannot do this well. Furthermore, they have people who pursue them that they cannot do public speaking. Thus, it makes them feeling down, less confidence and they believe that they cannot perform public speaking.

\section{d. Emotional State}

Emotional state is the fourth factor which influence someone self-efficacy. Based on interview with nineteen students, there are twelve students who think that they are getting emotional state, but its affect is different each other. Student 3 and student 4 feel nervous while they are performing or before they perform public speaking, but they think that it does not affect their performance since they believe that they can accomplish performing speech well.

Student 1, Student 6 and Student 10 are feeling anxiety and nervous. Thus, it makes them believe that they cannot do it and it will influence their performance. They think that they really cannot perform the best and they do not believe with their ability since they are getting fear and nervous. Furthermore, Student 1 and Student 10 do not have experience in performing public speaking. Thus, it just increases her nervous before performing.

Student 9, Student 7, Student 15, Student 16 and Student 13 have same feeling like Student 1, Student 6 and Student 10. They are feeling nervous, but its affect is different with Student 1, Student 6 and Student 10. They think that they are still able to perform speech, but their performance is not good since getting nervous lead them to decrease their confidence. Thus, they cannot show their best while performing public speaking.

Student 2, Student 12 and Student 18 also have same feeling. They feel nervous before performing. Thus, they think that it will affect their memory of their speech text. It will make them forget about what they will deliver to the audience.

\section{e. Other Factors}

Before asking specifically to the four factors, the researcher asked them about their first initial belief in performing speech. There are some factors which are different each other. Based on interview, belows are the other factors:

1. Confidence.

Student 4, Student 1, Student 6, Student 7, Student 13 and Student 2 believe that they have high self-confident. Student 4 said that the first student's belief that the student can perform prepared speech is self-confident. For the student, self-confidence lead her/him to act out in her/his speech well, so what she/he felt before performing speech or during performing speech will be lost by self-confidence.

2. Ability

Student 3 said that her ability becomes her first initial belief. She stated that having ability leads her to show her best performance speech. Thus, she highly believes that she can accomplish in performing speech by having ability in public speaking. Furthermore, for the student, ability provides tips the way to perform speech. Thus, ability leads the student to accomplish in performing prepared speech.

3. Doubt

Student 19 said that her first initial belief that influence her belief in execute public speaking is her doubt. She is not sure with her ability. Thus, it makes her that she cannot perform the best performance in speech. Her confidence is less than her doubt.

4. Do not have any experience.

Student 11 and Student 17 said that factor that influences their initial belief is that they do not have any experience. They said that they do not have any experience in performing. Thus, they said that they do not believe they can perform speech.

Student 11 said that do not have any experience in speech is being her first initial belief that the student cannot perform speech well since the student does not know the atmosphere in performing speech. Thus, the student does not know the way to perform speech well and how to make the audience interest with the student's performance in real condition.

Student 17 also said that the student did not have any experience in performing speech. Thus, it is being the student's first initial belief. The student said that what the student can master in performing speech since the student do not know the real condition in performing speech in public. Thus, it just decreases the student's anxiety in performing speech. 


\section{Teacher's Strategy in Public Speaking Program at SMKN 1 Lamongan.}

The teacher's strategies in teaching public speaking to the students were obtained from interview with the teacher who teaches public speaking program at SMKN 1 Lamongan. The interview results are described as follows:

a. Plan Moderately Challenging Tasks.

Challenging tasks do not provide simple task and it leads the students to struggle in doing their task. As the interview result with the teacher, it indicates that the teacher had planned the students' tasks. By all the tasks, there are two tasks which lead the students struggling in doing the tasks. The first was creating speech text and the second was analyzing the goodness and the lack of their speech text.

\section{b. Use Peer Models}

To help students acquire the way to perform public speaking, the teacher showed video regarding performing speech. The video was adjusted to students' level. They are as vocational high school students. Thus, the teacher provided speech video which was performed by vocational high school student. As the interview result with the teacher, she said that giving the video, it is expected that the students would have illustration regarding the way to perform speech at their level as vocational high school students.

\section{c. Affective Strategy}

To improve students' ability in performing prepared speech, the teacher also used affective strategy. Affective strategy provide responsibility to the students and natural communication. In providing responsibility to the students, the teacher gave students work individually and in a group regarding prepared speech. In individual work, the students were asked to make speech text which was based on theme given by the teacher and in a group they were also asked to make speech and they correct each other. To make natural communication to build up students' ability in speaking, the teacher was asked the students to discuss in group work by using English, so they spoke English naturally.

\section{d. Social Strategy}

In teaching social strategy, the teacher also used social strategy since the teacher leads the students to cooperate with other students in doing task. it can be seen by the teacher gave group work to arrange paragraphs of speech text.

e. Other Strategy (Strategy based on game activity) In teaching public speaking, the teacher also used other strategy which is not in Corno and Sellnow theory. This strategy is to build up fun activity by providing game. The game was providing chunks of speech text. Then, the students are asked to arrange the chunks of paragraph into the correct arrangement in speech text. Then, they are asked to stick their work and discuss it together at classroom. This activity was fun activity, but it also gave the students lesson regarding public speaking material.
The Students' Self-Efficacy and The Factors Influencing Students' Self-Efficacy of SMKN 1 Lamongan Students Who Participate Public Speaking Program.

The highest percentage is influenced by mastery experience, if people has more experience the higher self-efficacy they get since they think that they master and can accomplish similar think that they have done before.

In moderate level of self-efficacy, they are still influenced in positive way, such as: verbal persuasion and confidence in build up their self-efficacy, but different with the student in high level of self-efficacy, most of them are influenced by mastery experience which is the strongest way in buildup self-efficacy and they are also influenced by vicarious experience. In this moderate level, the student is less influenced in positive way. Furthermore, they are also influenced by emotional state in negative think. Thus, it leads them to believe that they can accomplish some aspects in speech. In moderate level of self-efficacy, it can be seen that the difference percentage is not too far.

In low level of self-efficacy, the students are much influenced by negative factors that can reduce their belief in performing speech. By three levels above, it can be seen that the higher people have self-efficacy, they master from their experience. In high level of selfefficacy, it can be seen that most of them are having experience regarding in performing speech. As Bandura stated that mastery experience is as the strongest way in buildup self-efficacy. Then, lower level student get, it can be seen that the students' believe is regarding to negative think that can make them belief that they cannot really accomplish the task

By the students' level, each statements have different scale each other since it is based on the students who believe that they can do the statement or not. There are some statements that reach high level of self-efficacy since many students believe that they can do that. As bandura stated that self-efficacy reflects to someone belief that they can execute the task.

In mastery experience, there is opposite between theory and finding with this research. Bandura stated that people with failure experience can make them weak in their own beliefs. In contrast, some students who have failure experience, they do not weak in their own beliefs. In fact, they master from their failure experience by keep improving from their mistakes. In essence, speech experience factor cannot only orients to the success experience but also failure experience. There are eight factors which influence students' self-efficacy in prepared speech. The eight factors are performing speech experience, vicarious experience, verbal persuasion, emotional state, confidence, ability, doubt and not experienced. As Bandura stated, self-efficacy is commonly influenced by four sources of mastery experiences, vicarious experiences, verbal persuasion, and emotional arousal. Then, confidence, ability, doubt and not experienced are the new findings of the students' first initial belief which influence their self-efficacy in performing prepared speech. 


\section{Teacher's Strategy in Improving Students' Self- Efficacy}

\section{a. Plan Moderately Challenging Tasks}

In plan moderately challenging tasks, the teacher asked the students to create speech text as the students' homework and to analyze the goodness and lack of their speech text. By both tasks, it leads the students struggling in process of doing both tasks. As Howard and Patrick stated that plan moderately challenging task, it gives struggling to the learners. As the similarity by Howard and Patrick theory with the students tasks given by the teacher, it can be seen that the students tasks indicates as challenging tasks since it leads the students to struggle in process of doing the task.

\section{b. Use Peer Models}

In using peer models, the teacher provided video regarding speech performance by vocational high school students. By the video, it is expected that the students had model in performing speech. As Howard and Patrick stated that a powerful way to help students acquire strategy is by giving them to watch other students do well on targeted tasks, but the models should be similar with the students. It can be age, gender, ability, interests, clothing, social circles, and achievement level. By the theory and the teacher had done, it can be seen that it has similarity that to acquire the targeted tasks, the learner is given model regarding targeted task which they learn and the model is adjusted by the students' level which are as vocational high school students.

\section{c. Affective Strategy}

The teacher also used affective strategy. As Oxford stated that affective strategy is helping students to generate student's positive feeling by provide responsibility to the students, increasing the amount of natural communication. In providing responsibility to the students, the teacher gives task individually about public speaking and the teacher also provides group work to increase natural communication since in group work the students speak English in natural setting to discuss their work.

\section{d. Social Strategy}

In social strategy, the teacher used cooperation. The students are asked to work in group and it leads them to cooperate with other students. According to Oxford, Social strategy provides some strategies: asking questions, cooperating with others, and empathizing with others. Cooperation is one of strategy which is used in social strategy. Cooperation lead the students to cooperate with other students and by implementing cooperation, it can increase confidence and reduce anxiety. As the theory stated and the strategy given by the teacher, it can be seen that the teacher implemented cooperation and cooperation is one of social strategy and it gives the positive outcome to the learners.

\section{e. Other Strategy}

The new finding from this study is that the researcher found another strategy which was used by the teacher in teaching public speaking. Teaching by chunks of paragraph which lead the students have fun activity in learning.

Four strategies have been done by the teacher, but there are also some students in moderate level of self-efficacy and low level of self-efficacy. It happened since the students do not come to the class continually since they have other activity at school or they get internship program. Thus, the strategy cannot directly reinforce to the students since they might not get the reinforcement when they do not come to the class.

\section{CONCLUSION}

By the result and discussion, it can be seen that the students who are having higher level they are influenced by positive factors. Furthermore, they are actively participated join public program. Thus, it makes them getting higher level since the teacher tried to reinforce the students' ability.

\section{REFERENCES}

[1] Anna Zajacova, Scott M. Lynch, Thomas J. Espenshade. "SelfEfficacy, Stress, and Academic Success in College". Princeton University. Research in Higher Education. Vol. 46, No. 6, 2005.

[2] Avifah, I'anatul. Undergraduate Thesis: “Teachers' SelfEfficacy in Managing Classroom Behavior Problems: A Study of Beginning Teachers at Intensive English". UIN Sunan Ampel Surabaya. 2013

[3] Bandura, Albert. "Self-Efficacy". Stanford University Vol.04, 1998.

[4] Bandura, Albert. Self-Efficacy Beliefs of Adolescents. (Copyright by Information Age Publishing). 2006.

[5] Bandura, Albert. Self-Efficacy in Changing Society. Cambridge: Cambridge University Press, 2009.

[6] Bandura, Albert. 1994. Self-Efficacy.In V.S. Ramachaudran (Ed.), Encyclopedia of human behavior (Vol. 4, 71-81, 1994). New York: Academic Press. (Reprinted in H. Friedman [Ed,], Encyclopedia of mental health. San Diego: Academic Press, 1998).

[7] Beverley Hancock, Elizabeth Ockleford, Kate Windridge, An Introduction to Qualitative Research. The NIHR Research Design Service for the East Midlands, 2009, 6.

[8] Blumenthal, Laura F, "Self-Efficacy in Low-Level English Language Learners". Portland State University, 2014.

[9] Dwyer, Karen Kangas, Ph.D. - Dennis A. Fus, Ph.D., "Perceptions Of Communication Competence, Self-Efficacy, and Trait Communication Apprehension: Is There An Impact on Basic Course Success?", University of Nebraska, 2002.

[10] Eubanks, Emily and Joy C, Jordan. Discovering the Treasure of Public Speaking. Florida: University of Florida, 2014.

[11] Gibson, Pattie. Administrative Office Management, Complete Course. (Acessed on: https://books.google.com on 21 November 2016, at 8 a.m.) 
[12] Gulten Genc, Emine Kulusakli, Savas Aydin, "Exploring EFL Learners' Perceived Sel Efficacy Beliefs on English Language Learning”. Australian Journal of Teacher Education. Vol 41. Issue 2. Article 4

[13] Margolis, Howard and Patrick P. McCabe. Improving SelfEfficacy and Motivation. Vol. 41, No. 4, 2016

[14] Oxford, R. Language Learning Strategie, What Every Teacher Should Know. Boston: Heinle \& Heinle Publishers (1990)

[15] Paul L. Witt, Mendy L. Roberts, Ralph Benhke. "Comparative Patterns of Anxiety and Depression in a Public Speaking Context”. Texas Christian University Vol.11, 2013.

[16] Quinn Patton, Michael and Michael Cochraan, "Guide to Using Qualitative Research Methodology" Medecins San Frontieres, 2002.

[17] Rahemi, Jamileh "Self-Efficacy in English and Iranian Senior High School Students Majoring in Humanities". Novitas Royal Research on Youth and Language. Vol 1(2)

[18] Roofi, Saeid. Bee Hoon Tan . Swee Heng Chan. Self-Efficacy in Second/Foreign Language Learning, (Malaysia: University Putra Malaysia, English Department, Modern Languages and Communication Faculty), 2012

[19] Schreiber, Lisa Ph.D, Introduction to Public Speaking. San Francisco: Millersville University, 2013.

[20] Warren, Jami Leigh. The Relationship between Service Learning and Public Speaking Self-Efficacy: Toward Engaging Today's Undergraduates". Theses and Dissertation. University of Kentucky. 2011 